\title{
TANGGUNG JAWAB HUKUM RUMAH SAKIT TERHADAP PASIEN HEALTH CARE-ASSOCIATED INFECTIONS (HAIS)
}

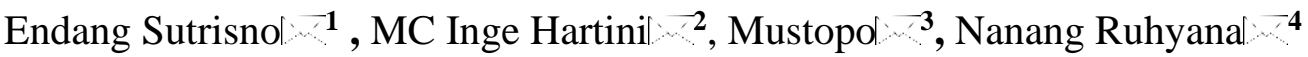 \\ Program Studi Ilmu Hukum Pascasarjana Universitas Swadaya Gunung Jati
}

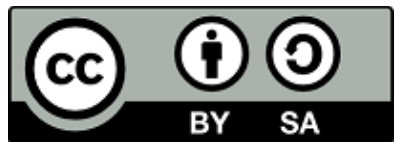

DOI: http://dx.doi.org/10.33603/hermeneutika.v3i2

\begin{abstract}
Abstrak: Rumah Sakit memiliki peran penting dalam mewujudkan derajat kesehatan masyarakat secara optimal, untuk itu dituntut agar mampu mengelola secara professional dan bertanggung jawab, mengusung arus keutamaan tanggung jawab profesi pada aspek kesehatan, khususnya tenaga medis dan tenaga keperawatan dalam menjalankan tugas dan wewenangnya. Health-Care Associated Infection (HAIs) penyebabnya terkait dengan proses dan sistem kesehatan. Aspek pertanggungjawaban hukum Rumah Sakit terhadap pasien yang terkena Health care-associated Infections (HAIs) menjadi fokus kajian, dengan pendekatan penelitian yuridis normatif, pada perspektif hukum sebagai kaidah tertulis yang tertuang dalam produk perundang-undangan yang berlaku. Rumah Sakit bertanggung jawab atas tindakan kelalaian tenaga kesehatan di Rumah Sakit, yang menyebabkan kerugian pada pasien, dibutuhkan adanya perlindungan hukum yang memadai sebagaimana tertuang dalam peraturan hukum secara normatif. Dalam hal perlindungan pasien, sebelum pelaksanaan pelayanan medis yang berkaitan dengan tindakan medis, tenaga kesehatan memberikan edukasi terhadap pasien terlebih dahulu, berupa penjelasan mengenai informasi, risiko yang terjadi, serta bentuk penanganannya. Apabila pasien merasa dirugikan dalam hal materiil maupun imateriil, pasien dapat mengajukan gugatan kepada Rumah Sakit yang melakukan kelalaian dan kesalahan, sebagai salah satu bentuk tanggung jawab hukum yang timbul.
\end{abstract}

Kata Kunci: Rumah Sakit; Tanggung Jawab Hukum; Health-Care Associated Infection (HAIs)

\footnotetext{
${ }^{1}$ Endang Sutrisno l.

Email: endangsutrisno94@gmail.com

${ }^{2}$ MC Inge Hartini

Email: inge@unswagati.ac.id

${ }^{3}$ Mustopo $1 \cdots$

Email: efin.mustopo@gmail.com

${ }^{4}$ Nanang Ruhyanal

Email: nanangruhyana18@gmail.com
} 


\section{PENDAHULUAN}

Kesehatan menyangkut keadaan sehat, secara fisik, mental spiritual maupun sosial yang memungkinkan setiap orang untuk hidup produktif secara sehat dan ekonomis, dan didalam konsideran Undangundang Nomor 36 tahun 2009 tentang Kesehatan menegaskan bahwa kesehatan merupakan hak asasi manusia salah satu unsur kesejahteraan yang harus diwujudkan sesuai dengan cita-cita bangsa Indonesia sebagaimana dimaksud dalam Pancasila dan Undang-Undang Dasar Negara Republik Indonesia Tahun 1945. Dalam subsistem sumber daya manusia kesehatan bahwa tenaga kesehatan merupakan unsur utama yang mendukung subsistem kesehatan lainnya, dengan tujuan pada tersedianya tenaga kesehatan yang bermutu secara mencukupi, terdistribusi secara adil, serta termanfaatkan secara berhasil-guna dan berdaya-guna, untuk menjamin terselenggaranya pembangunan kesehatan untuk meningkatkan derajat kesehatan masyarakat yang setinggi-tingginya.

Dalam upaya peningkatan kualitas hidup dan pelayanan kesehatan yang memadai, pemerintah maupun swasta menyediakan institusi pelayanan kesehatan yang disebut sebagai rumah sakit, merupakan penyelenggara pelayanan kesehatan perorangan secara paripurna yang menyediakan pelayanan rawat inap, rawat jalan dan gawat darurat disediakan untuk kepentingan masyarakat dalam hal peningkatan kualitas hidup. Kemajuan ilmu pengetahuan dan teknologi di bidang kesehatan telah berkembang dengan pesat dan didukung oleh sarana kesehatan yang semakin canggih, perkembangan ini turut mempengaruhi jasa professional di bidang kesehatan yang dari waktu ke waktu semakin

\footnotetext{
5 Bahder Johan, Hukum Kesehatan Pertanggungjawaban Dokter, (Jakarta, PT. Rineka Cipta, 2005), hlm.5

6 Endang Sutrisno, Bunga Rampai Hukum dan Globalisasi, (Yogyakarta: Penerbit Genta Press, 2009), hlm. 56.

${ }^{7}$ Endang Sutrisno, Tracing the Performance of Law in Indonesia (A Perspective of Thomas Kuhn's Normal
}

berkembang pula. Berbagai cara perawatan dikembangkan sehingga akibatnya juga bertambah besar, dan kemungkinan untuk melakukan kesalahan semakin besar pula ${ }^{5}$.

Rumah sakit harus mampu mengelola pelayanan kesehatan secara profesional, optimal, aman, dan bertanggung jawab sehingga unsur yang terlibat dalam pelayanan kesehatan tenaga medis, tenaga keperawatan harus mengutamakan dan memperhatikan norma hukum yang berlaku termasuk kebijakan yang menyangkut standar operasional prosedur yang harus dilakukan. Norma hukum mengandung tujuan untuk membangun kesejahteraan, keadilan, ketertiban, keamanan, dan kepastian hukum serta kemanfaatan. Keseluruhan pencapaian akhir eksistensi hukum di tengah-tengah masyarakat telah meneguhkan pentingnya peran hukum dalam proses perubahan dan pembangunan.

Kita sadari sepenuhnya pada sebagian besar bidang kehidupan masyarakat sekarang telah dilakukan penormaan terhadap tingkah laku manusia sehingga hukum melingkupi semua bidang. Penetrasi hukum ke dalam mmasyarakat yang sedemikian kental, berakibat pada adanya tuntutan untuk melakukan perubahan dan perkembangan dari hukum itu sendiri dan kaitannya dengan masalah-masalah sosial lain juga akan menjadi semakin intensif ${ }^{6}$. An approach that is still under further discussion through a more holistic alternative paradigm $^{7}$. Posisi Negara dalam tataran merumuskan norma hukum dan kebijakan harus lebih lebih progresif dan responsif perannya sebagai regulator, the government must be able to give affirmation to the community, the law that is made leads to the interests of the community and oriented towards social justice ${ }^{8}$. Sekalipun, dapat

Science), Journal of Law, Policy and Globalization, Vol.37, IISTE Knowledge Sharing Partners, 2015, page.126.

${ }^{8}$ Endang Sutrisno, Relations Between Legal Culture and Economic Empowerment among Marginalized Group of Farmers, Journal of Legal, Ethical and Regulatory Issues, Volume 22, Issue 3, June 2019, page 22-3-329. 
dipahami sistem hukum yang berlaku dapat dipengaruhi oleh berbagai elemen yaitu substansi, struktur dan budaya hukum, yang paling memberikan pengaruh besar yaitu budaya hukum masyarakatnya. Law is an important element in the development of politics and it makes the relationship with government policy clearer. Through legislation, the Government determines what it can do and what not to do. Law defined as legislation is a system of norms where the rule of law is arranged in unity within a hierarchical manner. The lower legal norms should not be contradictory to the higher legal norms ${ }^{9}$.

Kaidah hukum dalam ranah kesehatan menjadi sangat penting perannya, mengingat khususnya sehingga masalah tanggung jawab hukum harus diutamakan. Pembebanan hukum tersebut timbul oleh sebab tenaga kesehatan dimungkinkan tidak selamanya mampu memberikan layanan yang diharapkan oleh pasien. Kondisi tersebut mendudukan rumah sakit pada posisi yang vital. Pertanyaan yang paling penting adalah bagaimanakah tanggung jawab hukum rumah sakit dapat terjadi, terhadap pasien yang terkena Health CareAssociated Infections (HAIs).

\section{METODE PENELITIAN}

Metode pendekatan yang digunakan yaitu yuridis normatif dengan mengkaji produk peraturan perundang-undangan yang berlaku menyangkut Undang-Undang Nomor 44 Tahun 2009 tentang Rumah Sakit, Undang-Undang Nomor 29 Tahun 2004 tentang Praktik Kedokteran, dan UndangUndang Nomor 36 Tahun 2014 tentang Penegakan Disiplin Tenaga Kesehatan, keberlakuan tatanan hukum tersebut sangat dipengaruhi oleh banyak faktor dalam

\footnotetext{
${ }^{9}$ Endang Sutrisno - Isnaeni Jazilah, The Licensing Policy for Groundwater Extraction and Management for Hospitality Industry in Cities in Developing Countries, Journal Water Policy, IWA Publishing, Vol.21, Issue 3 June 2019, page 1-10.
}

realitas sosial yang terjadi di masyarakat. Fokus kajian pada taran teks-teks tertulis dari norma tersebut dalam upaya pencapaian tujuan hukum yaitu kepastian hukum serta rasa keadilan di masyarakat, khususnya di bidang kesehatan.

\section{LANDASAN TEORI}

Menurut hukum tanggung jawab adalah suatu akibat atas konsekuensi kebebasan seorang tentang perbuatannya yang berkaitan dengan etika atau moral dalam melakukan suatu perbuatan ${ }^{10}$. Pertanggungjawaban harus mempunyai dasar, yaitu hal yang menyebabkan timbulnya hak hukum bagi seorang untuk menuntut orang lain sekaligus berupa hal yang melahirkan kewajiban hukum orang lain untuk memberi pertanggungjawabannya. Menurut hukum perdata dasar pertanggungjawaban dibagi menjadi dua macam, yaitu kesalahan dan risiko. Dengan demikian dikenal dengan pertanggungjawaban atas dasar kesalahan (lilability without based on fault) dan pertanggungjawaban tanpa kesalahan yang dikenal (lilability without fault) yang dikenal dengan tanggung jawab risiko atau tanggung jawab mutlak (strict liabiliy). Prinsip dasar pertanggung jawaban atas dasar kesalahan mengandung arti bahwa seseorang harus bertanggung jawab karena ia melakukan kesalahan karena merugikan orang lain. Sebaliknya prinsip tanggung jawab risiko adalah bahwa konsumen penggugat tidak diwajibkan lagi melainkan produsen tergugat langsung bertanggung jawab sebagai risiko usahanya $^{11}$.

Pengertian pasien adalah seseorang yang menerima perawatan medis, berdasarkan ketentuan Pasal 1 Ayat(4) Undang-Undang Nomor 44 Tahun 2009

10 Soekidjo Notoatmojo, Etika dan Hukum Kesehatan, (Jakarta: Penerbit Rineka Cipta, 2010), hlm.28.

11 Titik Triwulan. Perlindungan Hukum Bagi Pasien, (Jakarta: Penerbit Prestasi Pustaka, 2006), hlm.49. 
tentang Rumah Sakit, menyebutkan bahwa pasien adalah setiap orang yang melakukan konsultasi masalah kesehatannya untuk memperoleh pelayanan kesehatan yang diperlukan, baik secara langsung maupun tidak langsung di Rumah Sakit. Dan menurut Pasal 1 Ayat(10) Undang-Undang Nomor 29 Tahun 2004 tentang Praktik Kedokteran, menyatakan pasien adalah setiap orang yang melakukan konsultasi masalah kesehatannya untuk memperoleh pelayanan kesehatan yang diperlukan baik secara langsung maupun tidak langsung kepada dokter atau dokter gigi. Berdasarkan beberapa pengertian tersebut dapat diambil kesimpulan bahwa pasien memiliki ciri-ciri yaitu setiap orang yang sakit, menerima/ memperoleh pelayanan kesehatan, secara langsung maupun tidak langsung, dari tenaga kesehatan yaitu dokter atau dokter gigi.

Pengendalian kejadian Health CareAssociated Infections (HAIs) mempunyai beberapa faktor yang berhubungan dengan perilaku perawat dalam mencuci tangan. Dan faktor-faktor yang mempengaruhi kepatuhan perawat terhadap tindakan pencegahan infeksi adalah faktor karakteristik individu (jenis kelamin, umur,jenis pekerjaan, masa kerja, tingkat pendidikan), faktor psikososial (sikap terhadap penyakit, ketegangan kerja, rasa takut dan persepsi terhadap risiko), faktor organisasi manajemen, faktor pengetahuan, faktor fasilitas, faktor motivasi dan kesadaran, faktor tempat tugas, dan faktor bahan cuci tangan terhadap kulit ${ }^{12}$.

Hubungan hukum antara perawat dengan pasien dan tenaga kesehatan di rumah sakit dalam upaya mencari kesembuhan, dikonstruksikan dalam hubungan perikatan dalam upaya pelayanan kesehatan di rumah sakit khususnya yang menyangkut perawat yaitu $^{13}$ :

a. Hubungan antara rumah sakit dengan perawat diatur oleh perjanjian kerja dalam Pasal 1601 KUH Perdata bagi rumah sakit swasta, sedangkan bagi

\footnotetext{
12 Tohamik, Pedoman Pencegahan dan Pengendalian Infeksi di Rumah Sakita dan Fasiitas Pelayanan Kesehatan Lainnya, (Jakarta : Penerbit EGC, 2003),
} hlm. 69. 76 Hermeneutika: Jurnal Ilmu Hukum Vol. 4, No. 1, Februari 2020 perawat yang bekerja di rumah sakit pemerintah tunduk pada ketentuan hukum kepegawaian. Berdasarkan Pasal 1601 KUH Perdata jo. 1601a hubungan perawat dengan rumah sakit termasuk dalam perjanjian perburuhan, yaitu persetujuan berdasarkan syarat tertentu pihak yang satu, dalam hal ini perawat, mengikatkan dirinya untuk dibawah perintah pihak lain, rumah sakit, untuk suatu waktu tertentu melakukan pekerjaan dengan menerima upah. Aspek keahlian dan keterampilan yang dimiliki oleh perawat niscaya menentukan macam dan lingkup tugas yang akan diberikan kepada perawat. Dalam melaksanakan tugasnya, perawat diikat oleh standar pelayanan keperawatan dan Kode Etik Keperawatan.

b. Hubungan antara dokter dengan perawat, dalam suatu tindakan medik tertentu dokter memerlukan bantuan perawat. Perawat dalam tindakan medis hanya sebatas membantu dokter, karenanya yang dilakukan sesuai order dan petunjuk dokter. Perawat tidak bertanggung jawab dan bertangung gugat atas kesalahan tindakan medis tertentu yang dilakukan oleh dokter. Perawat adalah orang yang memberikan paling banyak tindakan.

Sedangkan untuk hubungan antara dokter dan pasien pada prinsipnya ada dua hal penting yang harus diperhatikan yaitu bagaimana dokter menempatkan otonomi pasien sebagai individu khususnya dalam pengambilan keputudan medis dan bagaimana dokter membangun keharmonisan tersebut melalui komunikasi yang efektif. Selama ini dokter menempatkan dirinya dalam keputusan medis sebagai guardian dan yang paling serba tahu,

13 Praptianingsih, Kedudukan Hukum Perawat Dalam Upaya Pelayanan Kesehatan di Rumah Sakit. ( Jakarta: Penerbit PT. Raja Grafindo, 2006), hlm 85 
sehingga otonomi pasien kurang mendapat tempat. Pola hubungan dokter dan pasien seperti ini dapat diibaratkan sebagai hubungan antara ayah dan anak atau hubungan yang bersifat paternalistik.Sifat paternalistik ini menimbulkan ketidakseimbangan hubungan dan interaksi antara pasien dan dokter serta ditopang dengan penuh ketidakpastian.

Kondisi inilah yang menimbulkan hubungan "asimetris" antara dokter dan pasien. Selain itu, dengan adanya sifat paternalistik antara dokter dan pasien, selanjutnya akan melahirkan prinsip father know best (ayah yang paling tahu). Secara etimologi paternalistik berasal dari bahasa Latin (pater) yang artinya father atau ayah. Paternalistik, pada dasarnya didasari oleh prinsip etik dalam dunia medis yaitu beneficence (berbuat baik pada pasien), yang dalam konteks etika kedokteran yang dimaksud berbuat baik adalah sebagai kewajiban ${ }^{14}$. Premis dasarnya adalah bahwa dokter merupakan orang yang baik hati yang mempunyai pengetahuan dan ketrampilan yang mumpuni dan mempunyai niat baik untuk menolong pasien. Adanya hubungan yang bersifat "asimetris" antara dokter dan pasien, seperti disebutkan di atas, ada ketidakseimbangan yang melekat dalam hubungan tersebut, sehingga dapat merugikan salah satu pihak terutama pasien. Sampai saat ini, masih banyak dokter yang menganut prinsip paternalistik dalam membina hubungan dengan pasiennya, sehingga tetap mempertahankan sifat "asimetris"15.

Hubungan hukum ini bersumber pada kepercayaan pasien terhadap dokter sehingga pasien bersedia memberikan persetujuan tindakan medis (informed consent), yaitu suatu persetujuan pasien untuk menerima upaya medis yang akan dilakukan terhadapnya yang terkait dengan hubungan tersebut karena pasien itu mencari

${ }^{14}$ Bertens, Etika Bio Medis, (Yogyakarta: Penerbit Kanisius, 2011), hlm.67. pertolongan untuk penyembuhan penyakitnya, dalam hal ini kepada dokter atau rumah sakit. Hal ini membawa akibat bahwa hubungan pemberian pertolongan ini membuat pasien berada dalam suatu posisi yang lemah dan tergantung kepada dokternya, Seorang dokter mempunyai kedudukan yang lebih kuat, yaitu suatu profesi yang darinya banyak diharapkan dapat menghilangkan penyakit pasien. Secara sosiologis hubungan interaksi antara dokter dan pasien merupakan hubungan yang sangat pribadi antar individu.

Pasien memiliki otonomi yang besar. Dengan kata lain, pasien yang menentukan keputusan atas dirinya setelah mendapat informasi yang cukup dari dokternya. Secara konkret dokter adalah partner pasien dalam hal mencarikesembuhan penyakitnya dan kedudukan keduanya sama secara hukum. Pasien dan dokter sama-sama mempunyai hak dan kewajiban tertentu. Dari berbagai pola hubungan dokter dan pasien di atas, model hubungan mana yang masih kuat berlaku dalam praktik pelayanan medis, terutama di rumah sakit, masih sangat tergantung pada situasi dan kondisi serta budaya masyarakat masing-masing. Pilihan model paternalistik cocok diterapkan pada kondisi kedaruratan medis dan saat berhubungan dengan pasien yang mempunyai pengetahuan yang kurang atau ketika budaya setempat masih menempatkan dokter sebagai guardian. Model paternalistik sudah tidak cocok lagi diterapkan pada kelompok pasien yang berpendidikan dan sudah sadar hukum. Dalam praktik pelayanan medis, terutama di rumah sakit nampak bahwa hubungan dokter dan pasien masih tidak seimbang, karena dokter di rumah sakit secara ilmu medis mempunyai kedudukan yang lebih unggul dan mempunyai pengetahuan di bidang kedoketeran. Sementara itu, pasien berada dalam keadaan sakit, bingung, khawatir,

15 Suharjo B Cahyono, Membangun Budaya Keselamatan Pasien dalam Praktek Kedokteran, (Yogyakarta: Penerbit Kanisius, 2008), hlm.295. 
cemas dan pada umumnya tidak mengetahui atau menguasai tentang ilmu kedokteran. Oleh karena itu, dalam konteks ini harus diusahakan adanya keseimbangan. Dokter harus memberi penjelasan (informasi) tentang tindakan medis yang akan dilakukan dan apa sebabnya. Menurut Jay Katz ${ }^{16}$, dalam teorinya Idea of Informed Consent, mengemukakan bahwa keputusan tentang pemberian pengobatan atau perawatan kepada seorang pasien harus terjadi secara kolaboratif dan berdiskusi antara dokter dan pasiennya ${ }^{17}$.

\section{PEMBAHASAN}

Rumah sakit merupakan institusi pelayanan kesehatan yang menyelenggarakan pelayanan kesehatan perorangan secara paripurna yang menyediakan pelayanan rawat inap, rawat jalan, dan gawat darurat, sebagaimana dapat dilihat dalam ketentuan Pasal 1 angka 1 Undang-Undang Nomor 44 Tahun 2009 tentang Rumah sakit. Kegiatan rumah sakit dilakukan oleh tenaga kesehatan yang terorganisir, termasuk pelayanan diagnosis dan pengobatan pasien. Menurut Crawford Morris \& Alan Moritz ${ }^{18}$, rumah sakit adalah a place in which a patient receive food, shelter, and nursing care while receiving medical or surgical treatment, "or" an institution for the reception, care and medical treatment of the sick or wound-ed, also the building used or that purpo-se" or "a place where medicine is practiced by physician. Rumah sakit dibagi berdasarkan pengelolaannya, dibagi menjadi rumah sakit publik dan rumah sakit privat. Rumah sakit publik dikelola oleh pemerintah, pemerintah daerah (propinsi, kabupaten) ataupun yang dikelola oleh Badan hukum yang bersifat nirlaba, sehingga rumah sakit publik dapat

\footnotetext{
16 Veronica Komalawati, Peranan Informed Consent dalam Transaksi Terapeutik, (Bandung, Penerbit Citra Aditya Bakti, 2013), hlm.63.

17 Guwandi, Informed Consent and Informed Refusal, (Jakarta, Penerbit Fakultas Kedokteran Universitas

Indonesia, 2006), hlm.70.
}

disebut sebagai rumah sakit non-komersial. Rumah sakit pemerintah diselenggarakan berdasarkan pengelolaan Badan Layanan Umum atau Badan Layanan Daerah. Rumah sakit yang dikelola oleh pemerintah tidak dapat dialihkan menjadi rumah sakit privat (Pasal 20 Undang-Undang Rumah Sakit). Rumah sakit privat (swasta) dikelola oleh badan hukum dengan tujuan profit yang berbentuk Perseroan Terbatas atau Persero (Pasal 21 Undag-Undang Rumah Sakit), sehingga rumah sakit privat dapat sebagai rumah sakit yang komersial.

Tenaga kesehatan yang melakukan tindakan kelalaian sama dengan melakukan malpraktik. Malpraktik yang dilakukan oleh tenaga kesehatan, dapat berupa malpraktik medik dan malpraktik dibidang medik. Malpraktik di bidang medik, yaitu malpraktik yang dilakukan tenaga kesehatan ketika ia menjalankan profesinya di bidang medik. Dalam hal ini, dapat berupa perbuatan yang disengaja (intentional) seperti pada misconduct terntentu, tindakan kelalaian (negligence), ataupun suatu kekurang mahiran/ketidak kompetenan yang tidak beralasan (unrea sonable lack of skill), yang mengakibatkan luka, atau menderita kerugian pada pihak yang ditangani ${ }^{19}$. Makna malpraktik medik, menurut World Medical Association, adalah medical malpraktic involves the physician's failure to conform to the standard of care for treatmentof the patient's condition, ar lack of skill, or negligence in providing care to the patient, which is the direct cause of an injury to the patient. World Medical Association mengingatkan tidak semua kegagalan medik adalah malpraktik medik. Jika terjadi peristiwa buruk tidak dapat diduga sebelumnya (unforeseeable) pada saat dilakukan tindakan medis yang sesuai

\footnotetext{
18 Sofwan Dahlan, Hukum Kesehatan RambuRambu bagi Profesi Dokter, ( Semarang : Penerbit Badan Penerbit Universitas Diponegoro, 2003), hlm. 147

${ }^{19}$ Black Law Dictionary, Sevent Edition, Copy Right by West Group Co. 50. (West Kellogg Boulevard Po. Box 64526 St. Paul Minn, 55164-526, 1999), hlm. 111.
} 
standar tetapi mengakibatkan cedera pada pasien, maka hal ini tidak termasuk ke dalam pengertian malpraktik ${ }^{20}$. Letak perbedaan antara malpraktik di bidang medik dengan malpraktik medik terdapat unsur kejahatan atau perbuatan yang tidak senonoh (misconduct) pada malpraktik di bidang medik. Dalam malpraktik medik lebih ke arah adanya kegagalan (failure) dalam memberikan pelayanan medik terhadap pasien. Dengan demikian pengertian malpraktik di bidang medik pengertiannya lebih luas daripada malpraktik medik ${ }^{21}$. Jika ditinjau dari perspektif hukum maka malpraktik yang dilakukan oleh tenaga kesehatan, dapat merupakan criminal malpractice, civil malpractice, dan administrative malpractice ${ }^{22}$. the are factors that influence law enforcement. These factors have a neutral meaning so that the positive or negative impact lies in certain factors that influence $i t^{23}$

Tenaga kesehatan yang melakukan malpraktik di bidang medik, tetap dipertanggungjawabakan pada tenaga kesehatan tersebut. Malpraktik di bidang medik tidak menyangkut kegagalan dalam memberikan pelayanan medik, tetapi menyangkut adanya perbuatan yang tidak senonoh (misconduct) yang dilakukan oleh tenaga kesehatan ketika melakukan tugas. Pada umumnya bentuk malpraktik di bidang medik merupakan perbuatan melanggar rumusan tindak pidana yang diatur dalam hukum pidana. Dalam sistem pemidanaan hukum pidana dianut asas individual, artinya pertanggjawaban pidana dijatuhkan pada individu yang melakukan perbuatan

\footnotetext{
${ }^{20}$ M. Nasser, Penyelesaian Sengketa Medik Melalui Madiasi, Makalah Seminar Nasional Penegakan Hukum Kasus Malpraktik serta Perlindungan Hukum bagi Tenaga Kesehatan dan Pasien, 18 Juli 2009 di Unsoed Purwokerto, 2009, hlm. 6.

21 Angkasa, Malpraktik di Bidang Medik dan Malpraktik Medik dalam Perspektif Viktmologi dan Perlindungan Hukum bagi Pasien (Korban Malpraktik), Makalah Seminar Nasional tentang Penegakan Hukum Kasus Malpraktik serta
}

pelanggaran hukum pidana tersebut. Ketentuan dalam hukum pidana berlaku bagi setiap orang pada umumnya, sehingga termasuk tenaga kesehatan yang melakukan pelanggaran hukum pidana.

Berdasarkan Undang-Undang Rumah Sakit bahwa rumah sakit bertanggung jawab terhadap semua kerugian yang menimpa seseorang sebagai akibat dari kelalaian tenaga kesehatan di rumah sakit, sebagaimana ditentukan pada Pasal 46 Undang- Undang Nomor 44 tahun 2009 menjadi dasar untuk seseorang untuk meminta tanggung jawab pihak rumah sakit jika terjadi kelalaian tenaga kesehatan yang menimbulkan kerugian. Berdasarkan rumusan kaidah hukum tersebut, dapat ditafsirkan beberapa hal. Pertama, rumah sakit bertanggung jawab terhadap kerugian, sebatas akibat dari kelalaian tenaga kesehatan di rumah sakit; kedua, rumah sakit tidak bertanggung jawab semua kerugian seseorang, jika ternyata terbukti tidak ada tindakan kelalaian dari tenaga kesehatan di rumah sakit; ketiga, rumah sakit tidak bertanggung jawab terhadap tindakan kesengajaan tenaga kesehatan yang menimbulkan kerugian seseorang bukan menjadi tanggung jawab rumah sakit; dan keempat, rumah sakit bertanggung jawab terhadap tindakan kelalain tenaga kesehatan, jika kelalaian tersebut dilakukan dan terjadi di rumah sakit.

Dasar pembenaran/relevansi rumah sakit bertanggung jawab atas kelalaian tenaga kesehatan (khususnya dokter), dapat pula dilihat dari aspek kondisi hubungan terapetik (hubungan kepentingan medis)

Perlindungan Hukum bagi Tenaga Kesehatan dan Pasien, Unsoed, Purwokerto, 18 Juli 2009, hlm. 2.

${ }^{22}$ Sofwan Dahlan, Op.Cit, hlm.59.

${ }^{23}$ Endang Sutrisno -Taty Sugiarti - Novani Ambarsari Pratiwi, Environmental :aw Enforcement in Hazardous-Waste Management in West Java Indonesia: A Critical Trajectory of Green and Anthropogenic-Based Environmental Policy Orientations, International Journal of Scientific \& Technology Research, Vol.8, Issue 08, August 2019, page. 430 . 
antara pasien dengan rumah sakit. Pola hubungan terapetik di rumah sakit, dapat dalam bentuk hubungan pasien dan rumah sakit; pola hubungan pasien dan dokter.

Jika pola hubungan terapetik antara pasien dan rumah sakit, maka kedudukan rumah sakit sebagai pihak yang memberikan prestasi, sementara dokter hanya berfungsi sebagai employee (sub-ordinate dari rumah sakit) yang bertugas melaksanakan kewajiban rumah sakit. Dalam bahasa lain, kedudukan rumah sakit adalah sebagai principal dan dokter sebagai agent. Sedangkan pasien berkedudukan adalah sebagai pihak yang wajib memberi kontraprestasi. Hubungan seperti ini biasanya berlaku bagi rumah sakit milik pemerintah yang dokter-dokternya digaji secara tetap dan penuh, tidak didasarkan atas jumlah pasien yang telah ditangani atau pun kualitas serta kuantitas tindakan medik yang dilakukan dokter. Dengan adanya pola hubungan terapeti ini (hubungan pasien rumah sakit), maka jika terdapat kerugian yang diderita oleh pasien karena kelalaian dokter (tenaga kesehatan), maka dalam hal ini rumah sakit yang bertanggung jawab.

Pola hubungan pasien-dokter terjadi jika pasien sudah dalam keadaan berkompeten dan dirawat di rumah sakit yang dokter-dokternya bekerja bukan sebagai employee, tetapi sebagai mitra (attending physician). Pola seperti ini menempatkan dokter dan rumah sakit dalam kedudukan yang sama derajat. Dokter sebagai pihak yang wajib memberikan prestasi, sedangkan fungsi rumah sakit hanyalah sebagai tempat yang menyediakan fasilitas (tempat tidur, makan minum, perawat/ bidan serta sarana medic dan nonmedik). Konsepnya seolah-olah rumah sakit menyewakan fasilitasnya kepada dokter yang memerlukannya. Pola seperti ini banyak dianut oleh rumah sakit swasta di mana dokternya mendapatkan penghasilan berdasarkan jumlah pasien, kuantitas dan kealitas tindakan medik yang dilakukan. Jika dalam satu bulan tidak ada pasien pun yang dirawat maka bulan itu dokter tidak menghasilan apa-apa. Dengan pola hubungan pasien dokter, jika ada kelalaian dokter (tenaga kesehatan) yang menyebabkan kerugian pada pasien, maka dokter (tenaga kesehatan) yang bertanggung jawab, dan bukan menjadi tanggung jawab rumah sakit.

Ada beberapa macam pola yang berkembang dalam kaitannya dengan hubungan kerja antara tenaga kesehatan (dokter) dan rumah sakit antara lain: dokter sebagai tenaga kerja (employee); dokter sebagai mitra (attending physician); dokter sebagai independent contractor ${ }^{24}$. Masingmasing dari pola hubungan kerja tersebut akan sangat menentukan apakah rumah sakit harus bertanggung jawab atau tidak terhadap kerugian yang disebabkan oleh kesalahan dokter serta sejauh mana tanggung jawab/gugat yang harus dipikul. Mengenai dokter sebagai employee dan dokter sebagai attending physician sudah cukup disinggung di bagian depan. Seperti telah disinggung di atas tentang pola hubungan terapetik, jika hubungan kerja dokter sebagai employee, maka jika terjadi kerugian pada pasien karena tindakan dokter, pihak rumah sakit yang bertanggung jawab. Demikian pula jika dokter sebagai attending physician, jika ada kelalaian dokter (tenaga kesehatan) yang menyebabkan kerugian pada pasien, maka dokter (tenaga kesehatan) yang bertanggung jawab, dan bukan menjadi tanggung jawab rumah sakit.

Untuk menjelaskan tentang dokter sebagai independent contractor, diberikan ilustrasi sebagai berikut. Di dalam suatu kegiatan operasi merupakan tindakan medik yang memerlukan tim dengan berbagai latar belakang keahlian, terdiri atas: operator dan ahli anestesi. Tim tersebut dapat berupa tim tunggal dengan pimpinan seorang ahli bedah yang akan bertindak sebagai captain of the ship di mana dokter anestesi termasuk di dalamnya atau bisa juga berupa 2 tim yang terdiri atas tim operator (terdiri ahli bedah dan asisten dan perawat) dan tim anestesi

${ }^{24}$ Ibid, hlm. 157. 
(terdiri ahli anestesi dan perawat anestesi) dengan catatan masing-masing tim punya pimpinan sendiri-sendiri yang akan bertindak sebagai captain of the ship di dalam timnya.

Dokter ahli anestesi atau tim anestesi bekerja secara mandiri (tidak sebagai subordinate-nya operator) maka kedudukan dokter atau tim anestesi tersebut adalah sebagai independent contractor. Tetapi konsep independent contractor hanya bisa diterapkan bila kedudukan dokter ahli anestesi di rumah sakit sebagai attending physician. Kedudukan anggota tim, baik anggota tim operator maupun anggota tim anestesi, dapat bermaam-macam. Jika dokter bekerja sebagai attending physician, maka ia bisa saja menggunakan asisten atau perawat yang merupakan employee dari rumah sakit. Dalam hal ini maka kedudukan asisten atau perawat di ruang operasi adalah sebagai borrowed servant. Apabila operator menggunakan asisten atau perawat yang bukan merupakan employee rumah sakit maka kedudukan asisten atau perawat tersebut menjadi sub-ordinate dari operator, bukan sebagai tenaga pinjaman rumah sakit. Dengan uraian di atas, dengan pola hubungan dokter sebagai independent contractor, jika terjadi kerugian pada pasien karena kelalaian dokter ini, maka rumah sakit tidak bertanggung jawab.

Rumah sakit, baik yang dikelola oleh pemerintah maupun swasta, merupakan organisasi yang sangat komplek. Di tempat ini banyak berkumpul pekerja professional dengan berbagai macam latar belakang keahlian dan peralatan yang digunakan. Semakin besar dan canggih suatu rumah sakit semakin komplek pula permasalahannya. Oleh sebab itu tidaklah mudah menentukan tanggung jawab rumah sakit. Selain pola hubungan terapetik dan pola hubungan kerja tenaga medik, penyebab terjadinya kerugian itu sendiri juga sangat menentukan sejauh mana rumah sakit harus bertanggung gugat. Berdasarkan uraian tersebut di atas, maka dapat diketahui sejauhmana rumah sakit harus bertanggung jawab sangat tergantung pada pola hubungan terapetik yang terjadi dan pola hubungan kerja antara tenaga kesehatan dengan rumah sakit (status tenaga kesehatan).

Berdasarkan uraian di atas, tampak jelas bahwa rumah sakit pemerintah yang semua tenaga medik maupun non medik bekerja sebagai employee maka tanggung gugat dari ke empat hal di atas sepenuhnya menjadi tanggung gugat institusi tersebut, dengan catatan, untuk rumah sakit pemerintah yang melaksanakan program swadana masih diperlukan klarifikasi konsep sehingga implikasi hukumnya menjadi jelas. Persoalannya bukan saja tidak adil tetapi juga tidak logis membebankan tanggung gugat kesalahan medik seluruhnya kepada pihak rumah sakit, sementara dokter yang juga menikmati jasa medik berdasarkan presentase dapat bebas dari tanggung gugat atas kesalahannya sendiri. Rumah sakit sebagai badan hukum (korporasi) dapat dituntut dan dipertanggungjawabkan atas tindakan-tindakan malpraktik tenaga kesehatan di rumah sakit.

Jadi tidak mudah untuk menentukan jenis kelalain tenaga kesehatan yang merugikan seseorang dan menjadi tanggung jawab rumah sakit. Jika terjadi malpraktik, maka dilakukan klarifikasi terlebih dahulu termasuk malpraktik medik atau malpraktik di bidang medik. Jika ternyata merupakan malpraktik medik, hal ini ditekankan kepada sejauhmana tenaga kesehatan dalam memberikan pelayanan medik ini sesuai dengan standar. Jika tenaga kesehatan telah melakukan sesuai standar, dan tidak ada tindakan kelalaian serta telah sesuai dengan kemahiran/ kompetensinya, maka akan sulit dikatakan ada malpraktik. Namun demikian, dengan adanya ketentuan dalam UndangUndang Rumah Sakit, yang mengatur bahwa rumah sakit akan bertanggung jawab secara hukum terhadap kelalaian tenaga kesehatan, sangat wajar jika terjadi malpraktik medik akan menjadi tanggung jawab pihak rumah sakit, dan bukan menjadi tanggung jawab 
tenaga kesehatan. Pihak rumah sakit sebagai pengelola pelayanan kesehatan masyarakat, dengan untuk melindungi pasien dan masyarakat serta melindungi sumber daya di rumah sakit, sesuai dengan ketentuan Pasal 46 Undang-Undang Rumah Sakit sebagai pihak yang bertanggungjawab secara hukum.

Untuk malpraktik di bidang medik yang dilakukan oleh tenaga kesehatan, masih perlu diklarifikasi. Jika malpraktik di bidang medik berupa kesengajaan yang melanggar ketentuan hukum pidana, hal ini identik dengan kesengajaan melakukan tindak pidana. Oleh karena itu, menjadi tanggung jawab secara individual, dipertanggungjawabkan kepada tenaga kesehatan tersebut. Jika malpraktik di bidang medik dalam bentuk kelalaian sebagaimana diatur dalam hukum pidana (misalnya: kealpaan yang menyebabkan kematian, luka berat, ataupun timbul penyakit), dapat dipertanggungjawabakan kepada individu tenaga kesehatan tersebut, atau kelalaian ini dipertanggungjawabkan kepada rumah sakit. Kelalaian tenaga kesehatan ini dipertanggungjawabkan pihak rumah sakit, jika tenaga kesehatan tersebut merupakan tenaga kerja dari rumah sakit tersebut.

\section{KESIMPULAN}

Pertanggungjawaban rumah sakit terhadap pasien yang terkena Health-Care Associated Infection HAIs atas tindakan kelalaian tenaga kesehatan di rumah sakit, yang menyebabkan kerugian pada seseorang/pasien, dengan dasar secara yuridis, hal ini merupakan penerapan ketentuan Pasal 1367 KUH Perdata, dan Pasal 46 Undang-Undang Nomor 44 Tahun 2009 tentang Rumah Sakit serta standar profesi dan akreditasi pelayanan kesehatan secara internasional. Pertanggungjawaban rumah sakit terhadap pasien tersebut, atas kelalaian tenaga kesehatan termasuk jenis malpraktik medik, dan yang bersangkutan tetap dapat dipertanggungjawabkan secara hukum.

\section{DAFTAR PUSTAKA}

Angkasa, Malpraktik di Bidang Medik dan Malpraktik Medik dalam Perspektif Viktmologi dan Perlindungan Hukum bagi Pasien (Korban Malpraktik), Makalah Seminar Nasional tentang Penegakan Hukum Kasus Malpraktik serta Perlindungan Hukum bagi Tenaga Kesehatan dan Pasien, Unsoed, Purwokerto, 18 Juli 2009, hlm. 2.

Black Law Dictionary, 1999, Sevent Edition, Copy Right by West Group Co. 50. West Kellogg Boulevard Po Box 64526 St. Paul Minn, 55164-526.

Bahder Johan, 2005, Hukum Kesehatan Pertanggungjawaban Dokter, PT. Rineka Cipta, Jakarta.

Bertens, 2011, Etika Bio Medis, Kanisius, Yogyakarta.

Endang Sutrisno, 2009, Bunga Rampai Hukum dan Globalisasi, Genta Press, Yogyakarta.

Endang Sutrisno, Tracing the Performance of Law in Indonesia (A Perspective of Thomas Kuhn's Normal Science), Journal of Law, Policy and Globalization, Vol.37, IISTE Knowledge Sharing Partners, 2015, page. 126.

Endang Sutrisno, Relations Between Legal Culture and Economic Empowerment among Marginalized Group of Farmers, Journal of Legal, Ethical and Regulatory Issues, Volume 22, Issue 3, June 2019, page 22-3-329.

Endang Sutrisno - Isnaeni Jazilah, the Licensing Policy for Groundwater Extraction and Management for Hospitality Industry in Cities in Developing Countries, Journal Water Policy, IWA Publishing, Vol.21, Issue 3 June 2019, page 1-10.

Endang Sutrisno -Taty Sugiarti - Novani Ambarsari Pratiwi, Environmental: Law Enforcement in Hazardous-Waste Management in West Java Indonesia: A Critical Trajectory of Green and Anthropogenic-Based Environmental Policy Orientations, International Journal 
of Scientific \& Technology Research, Vol.8, Issue 08, August 2019, page.430.

Guwandi, 2006, Informed Consent and Informed Refusal, Fakultas Kedokteran Universitas Indonesia, Jakarta.

M. Nasser, Penyelesaian Sengketa Medik Melalui Madiasi, Makalah Seminar Nasional Penegakan Hukum Kasus Malpraktik serta Perlindungan Hukum bagi Tenaga Kesehatan dan Pasien, 18 Juli 2009 di Unsoed Purwokerto, 2009, hlm. 6.

Praptianingsih, 2006, Kedudukan Hukum Perawat Dalam Upaya Pelayanan Kesehatan di Rumah Sakit, PT. Raja Grafindo, Jakarta.

Sofwan Dahlan, 2003, Hukum Kesehatan Rambu-Rambu bagi Profesi Dokter, Badan Penerbit Universitas Diponegoro, Semarang.
Suharjo B Cahyono, 2008, Membangun Budaya Keselamatan Pasien dalam Praktek Kedokteran, Kanisius, Yogyakarta.

Soekidjo Notoatmojo, 2010, Etika dan Hukum Kesehatan, Rineka Cipta, Jakarta.

Titik Triwulan. 2006, Perlindungan Hukum Bagi Pasien, Prestasi Pustaka, Jakarta.

Tohamik, 2003, Pedoman Pencegahan dan Pengendalian Infeksi di Rumah Sakita dan Fasiitas Pelayanan Kesehatan Lainnya, EGC, Jakarta.

Veronica Komalawati, 2013, Peranan Informed Consent dalam Transaksi Terapeutik, Citra Aditya Bakti, Bandung. 